\title{
Examination of Socio-Economic and Socio-Cultural Factors Influencing Aspiration Levels of Youth with respect to their Education Levels: an Experimental Examination
}

\author{
Pabitra Kumar Das, Jayant Kumar Panigrahi, Iswar Chandra Naik, Biswajit Das
}

\begin{abstract}
With changing socio-economic backdrops, increasing opportunities for education, exposures of media and technology, the youth irrespective of socio-cultural differences are having more aspirations. For the youth of developing countries, the government, non-govt. and international non-govt. organizations are working to improve their overall status by implementing several programs and schemes. Exclusively raising the status of tribal youth living in remote rural areas in Odisha, India, many special programs is there to assist them. The study explores into tribal youth's aspiration aiming to assess whether their aspirations bear a resemblance to that of the non-tribal youth studying in colleges.

This study mainly focuses on youth between the age group of seventeen to twenty-three years on what they aspire to achieve i.e. to become and have in their personal lives. The data was collected randomly from twelve colleges (6 colleges each in urban and remote rural areas) and descriptive statistics was used for analysis. The results show that youth's aspirations are similar in kind but only differ in degrees. The youth are found not so inclined to politics, entrepreneurship and business but they aspire to have a job especially govt. employment. Moreover, their socio-economic family backdrops and educational level don't bear many relationships in influencing their aspirations. The study implications are discussed in the context of policy and programs for youth development in India.
\end{abstract}

Index Terms: Youth; Aspiration; Demographic dividend; Employment; Education

\section{INTRODUCTION}

Youth are the change-makers of any country. Youth can be termed as a 'transition period while the individual prepares himself or herself to become a responsible and productive citizen of the country'. National Youth Policy (2014), India, defines youth is 'in the age group of 15-29 years', whereas United Nations defines 'young people as a person between 15 and 24 years of age'. In India, approximately 600 (2018, the guardian.com) million youth make it the youngest country and in the coming 2020, the average age of Indians is going to be 29 years. So the demographic dividend ushers window of opportunities and in this context youth aspiration is the key for augmentation of development. Pragmatically, the country's aspiration reflects in youth aspiration and vice

Revised Manuscript Received on November 22, 2019.

Pabitra Kumar Das, Doctoral Scholar, School of Humanities, KIIT University, Bhubaneswar, India.

Jayant Kumar Panigrahi, Associate professor, ICER, New Delhi, India.

Iswar Chandra Naik, Associate Professor, School of Social Service Administration, KIIT University, Bhubaneswar, India.

Biswajit Das, Professor, School of Management, KIIT University, Bhubaneswar, India versa, provided with right kind of opportunities in education and employment for the youth.

Technological advancement and high-speed media have shortened the distance between rural and urban youth and discriminatory treatment towards soft gender are also transformed in many societies, at least in areas of education and career selection. This results in wide awareness among literate and educated youth on what is going in and around the country and the world. In the last decade youth participation significantly increased in higher education and in the workforce, but the majority remains in secondary level and informal sectors and women workforce participation are low. Now the country's NDP stands on 11.52 at the current price (2016-2017, data.gov in) whereas, in Odisha, it is a little higher. Prospective development of Scheduled Castes and Scheduled Tribes and Minorities is still a far cry. On the other hand, the dark side of youth-insurgency activities, gender-based violence, trafficking, religious intolerance, road accident, vandalization by caste-based groups, drug and alcohol addictions etc have too increased as per National Crime Record Bureau data (NCRB 2018, India). So the most important question is 'Can youth be considered as resource or liability?'

Aspiration of a person can be numerous but it little differs from expectation. Expectation occurs when an individual wants to have a particular thing from outside only whereas, in the case of aspiration, it is both intrinsic and extrinsic, it is more from within to have or become. So to fulfill his or her aspiration the person needs preparation and opportunities, while these two are met, success comes to the person. So for the youth in the country, there are policies and programs to address their extrinsic demands and needs, thus such mechanisms avoid threats and utilize youth potentials to contribute to socio-economic progress. Today, in the globalized economy the country has secured 6th position (2018) and is going to become 4th, would only be possible with maximum use of its demographic dividend transforming into human capital i.e. youth are to be capacitated with enough competence to compete in the global competitiveness.

\section{BRIEF LITERATURE SURVEY ON YOUTH}

India is in the transition from rural to urban; it is especially true as youth aspiration concerns. A pivotal question is whether the youth of the country would be resource or liability. Youth aspiration encompasses various different areas like educational, occupational, career, lifestyle and so on. These different types of aspiration have different sociological, economic and 
psychological connotations that influence not only the lives of the youth but also the people living around them. Looking at the brighter side, the demographic advantage India possesses now is far better than the natives like Bangladesh, Nepal, Bhutan, Pakistan and Sri Lanka; even HDI (Human Development Index) its position is 130 (HDI-130 UNDP2018), is little ahead of neighboring countries. But every development activity for the mass undoubtedly has a positive impact and it has its flipsides too; inside India, there are several social issues that directly emanate from youth's experiences. Some of the major issues related to country's youth are e.g. unemployment, lack of opportunity for higher education, health issues, substance abuse and others; the youth in the tribal hinterland have these problems along with the others like alienation, migration and insurgency activities too.

The recent report 'The ILO's Youth and the Future of Work Survey' (YFoW) showed 'that over half of the young people in developed countries and about one-third in emerging and developing countries view their future working life with fear or uncertainty'. Although fear or uncertainty is the opposite of optimism; the youth aspiration of developing countries for a stable job appeared stronger than those of developed countries. Unemployment scenario of the country indicates an alarming situation. Workforce participation of youth in the age group 15 to 29 years was $63.1 \%$ (male) and $18.3 \%$ (female) in the year 2011-2012. For the same age group, unemployment rates were $6.1 \%$ for male and $7.7 \%$ for female respectively in rural areas, whereas in the urban areas, it was $8.9 \%$ for male and $15.8 \%$ for female. Arup Mitra and Sher Verick (2013) in their working paper shared different nuance of country's youth suffering from 'underemployment, unemployment' and especially rural youth although they raised their educational status, could not get a foothold in 'formal employment' sectors. Their opinion, 'creating jobs for young people are a major challenge around the world' is critical in the context of the largest youth population in the country. Periodic Labour Force Survey (PLFS 2017-2018, India) showed highest unemployment rate for all demographics in the last three decades; urban women were found to highest unemployed and in rural areas, the rate was raised by $4 \%$ points and particularly youth age group (15-29) had the highest rate of unemployment. Unemployment rate in illiterate is less as compared to educated youth. Youth Survey (2015) carried out with 5202 urban youth in Indian metropolis by HT-MARS Poll, found $53.6 \%$ youth were more ambitious than their previous generation; the young mass was more positive about access, opportunities and success; and women (49.7) outdid the men (43.2\%) in self-confidence level for achieving their goals.

Youth aspiration for health and wellbeing, the survey (HT MARS Poll, 2015) revealed that the majority in this Z generation solely focused on happiness and happiness is a state of mind. With rising consumerism at the wake of advertising and electronic media, the youth enjoyed life scot-free; they just gave importance to their present life. In the survey respondents, $31.9 \%$ shared their life's biggest aim was to enjoy it fully. It was more important to them than living a healthy life $(21.5 \%)$, financial freedom $(9.7 \%)$, and pursuing passions $(9.3 \%)$. Health and substance abuse issues among the youth especially the age group (15-24) was found highest in number (NFHS2018). Roy. K, Sinde. S, Sarkar. B.K et.al (2019) shared that a meta-analysis had reported $' 6.5 \%$ of the community samples and $23.3 \%$ of school samples significant mental health morbidity'. Prof. A. Mahendran (2015) highlighted health and behavioural problems would likely to increase in the coming years. Prof. J. Satia (2018) referring to National Family Health Survey ((NFHS2015-16) revealed that early youth were the most victims of problems like RTI, STI, HIV, anemia, malnutrition, substance abuse, road traffic injuries, violence and suicide. Therefore, investment in education and health can transform the lives of the youth especially living in less-privileged areas, rural areas and generate high income and social benefits.

Studies on youth highlight another rubric and this is bleak for development; alienation and insurgency; alienation in India had its long past as because of social, cultural and political interlocking of the country's social structure and system. Singh. B.L, Singh. A.K. and Rani. A. (1996) found technically and non-technically unemployed youth had greater vulnerability to the feeling of alienation. Unemployment was the greatest cause of alienation among the youth in India (Mallik,2014), many among the youth felt the cause as 'absence of common frame of fundamental rights'. The Economic Times (Jan 2018) reported other accounts of the feeling of alienation; caste-based violence resulted in 11 dead in Mumbai while a movement was there for social and political changes. Alienation and insurgency are a yet formidable force of youth of Indian state named Jammu and Kashmir (A.A Wani, ORF's series 'National Security' 2015). Recent trends in newspaper vignettes reveal Muslim youth were found to be new terror recruits and tribal youth were in local insurgency activities. The Indian Risk Survey (IRS 2015 and 2018) showcased the rising threat of terrorism and insurgency activities which youth were engaged in and targeted for the exploitation of internal peace of the country. This terrorism and insurgency were found among the top three risks in the eastern region; states e.g. Odisha, Jharkhand, Chhattisgarh, Bihar, West Bengal and Andhra Pradesh are in this region. Vasabjit Banerjee (2017) shared the dynamics behind Maoist activities in a cross-sectional study, argued that 'inequality of wealth in the states, inefficient government, and disgruntled provocateur' were responsible for it.

Let us now deal with the question of migration in relation to the aspiration of youth. World Economic Forum (2017) shared India had 139 million internal migrants. The report demonstrated population explosion and poverty-induced situations where the causes of migration from other parts to the cities in India. The Promise of development; actual realities and multitudinous problems what the rural youth experienced, they aspired for cities as cities especially metropolis claimed for the face of development and aspiration of modernity. Kunduri E (2016) in her field study, suggested 'a large proportion of young migrants move to the cities for aspirational reasons'. "What am I educated for if I had to plow the fields only", indirectly reflected the aspiration of the educated youth of rural India.

Therefore, the essence is youth and their aspiration; provided opportunities and they can do anything. Youth aspiration can replace politics, society and economy of the country, 'Shining India'. 


\section{CONTEXT OF THE STUDY}

The general explanation of the goal of the study was to find out whether a difference exists in the territory, social class (tribe and non-tribe), gender, economic status on youth aspiration. Odisha was selected as the important context for studying youth aspiration; the changing scenario of the social, economic and demographic condition presents good opportunity to explore into this topic. Just two decades ago the state ranked among the most lagging and underdeveloped states in India (Census of India 2001) in perspectives of poverty, illiteracy, health, unemployment, migration, atrocities and insurgency activities etc.

The present demographic status of youth is far better than the other states like Jharkhand, Bihar and Chhattisgarh in India. Overall, youth participation in education and labour force has been increasing; poverty reduced, health status improved and antisocial activities including incidents of atrocities and insurgency too decreased, making Odisha one of the top-performing forerunner state in terms of development. Economy, infrastructure, education, health, and inclusive development the state ranked $17 \mathrm{th}, 12 \mathrm{th}, 11 \mathrm{th}, 11 \mathrm{th}$, and 12th respectively in the country as per 2017 records, (India Today Web Desk, November 2018 ).

Aiming youth especially college-going youth regards as the key to the state's development process and arresting social as well as economic issues. It can be done by addressing aspiration of the youth; because comparatively this cohort appears to be more empowered. Education and exposures of social, political and economic milieu play already significant influence in their lives. Age group (14-29 years), the youth comprises more than $41 \%$ of the state's population and about $15 \%$ to $18 \%$ belong to the tribals. Strikingly, literacy level rises, but there is very marginal enrollment in higher education and participation in the formal workforce by the tribal youth. Especially when the concern is of social hierarchy in the state of Odisha, tribal and non-tribal makes distinguished differences in terms of lifestyles, occupations, livelihoods and in terms of accessibility and participation in different social, cultural and political affairs. Youth with high aspiration is likely having higher chances of entering in potential career and maintaining sound wellbeing, this contributes to the development of society; likewise, a section in society youth who don't have or have low aspiration leads to underdevelopment results inequalities and disproportionate growth which is against inclusive development of the state. Therefore, exploration of youth aspiration that yields advantageous possibilities for the competitiveness of the state and is key futuristic indicator for the need for investment in human and social capital, is incredibly significant in this context.

\section{OBJECTIVES}

The objectives of the study:

1. To identify the aspiration of college-going youth.

2. To assess the difference in aspiration level between tribal and non-tribal youth studying in rural and urban colleges.

3. To compare the relationship between aspiration level and socio-economic status of youth.

\section{HYPOTHESES}

1. There is no significant difference between male and female in their level of aspiration
2. There is no significant difference between tribal and non-tribal youth in their level of aspiration.

3. There is no significant difference in aspiration level of youth studying in rural and urban colleges.

4. There is no significant difference in aspiration level of youth belonging to different age groups.

5. There is no significant difference in aspiration level of youth belonging to different socioeconomic status groups.

\section{METHODS}

The sample consisted of 384 college-going students (196 male, 188 female), out of which 184 students were from rural colleges and 200 students were from the capital region of the state. Rural participants were from comparatively three backward districts (Koraput, Bolangir and Kalahandi) in the state. Based on the location of the colleges in rural and urban areas, first 4 numbers of clusters were made and from each cluster 3 number of colleges were selected and finally the stratified random method was adopted for sampling. For data collection, prior permission was taken from the principals of the selected colleges and the students voluntarily participated in this investigation. 'Youth Aspiration Questionnaire' consisted of three partially structured questions and a scale measuring achievement and educational aspiration (a self-reported form) used exclusively to measure the aspiration level of the respondents. In the domain of the participants' immediate expectation and aspiration, they were probed with the question (I) 'What will you do immediately after completion of your college education?' Second question, (II) 'What is your aspirational role in your future career?' In question number II, response options are graded according to career ranking - high, medium and low based on the social perception of prestige and earning. In addition, 3 to 4 career roles were explicitly mentioned to each rank and some roles were clubbed, and total 10 career roles were put in ascending order. The prospective question was (III) 'What will you aspire to possess that you consider as achievement in the next 10 years of your life? The scale comprised with 16 statements and rating ranging from 0 to 4 for each statement: (0) Not at all true of me, (1) Slightly true of me, (2) Moderately true of me, (3) Quite a bit true of me, (4) Very true of me.

The investigator developed data collection tools with the assistance of university research faculties (KIIT University and KISS University, India), primarily after having multiple rounds of focused group discussion with 110 youths studying in these two universities. For analysis, descriptive statistics such as measures of frequency, percent; and to test hypotheses ANOVA, and independent t-test were used in this research.

\section{RESULT AND DISCUSSION}

The study result shows the respondents were from different demographic backgrounds although the sample size of different groups was almost the same without much difference. 
Examination of Socio-Economic and Socio-Cultural Factors Influencing Aspiration Levels of Youth with Respect to their Education Levels: An Experimental Examination

Table: 1: Respondents' Demographic Profile

\begin{tabular}{|c|c|c|c|}
\hline Variabled & Group $^{\circ} \alpha$ & Frequencya & Percentage $\cdot(\%) a$ \\
\hline \multirow{2}{*}{ Gender } & Maled & 1960 & 51.00 \\
\hline & Femaled & $188 a$ & 49.00 \\
\hline \multirow{2}{*}{ Category $\alpha$} & Scheduled Tribed & 1940 & 50.50 \\
\hline & Non-Tribed & 1900 & 49.50 \\
\hline \multirow{2}{*}{ Respondents-(location)a } & Rurala & $184 a$ & 47.90 \\
\hline & Urband & 2000 & 52.10 \\
\hline \multirow{3}{*}{ Aged } & $17-190$ & $212 a$ & 55.20 \\
\hline & $19-210$ & $112 \alpha$ & 29.20 \\
\hline & $21-23 \alpha$ & $60 a$ & 15.60 \\
\hline \multirow{2}{*}{$\begin{array}{l}\text { Education } \\
\text { (pursuing)a }\end{array}$} & Higher Secondary & $188 a$ & 49.00 \\
\hline & Graduated & 1960 & 51.00 \\
\hline \multirow{3}{*}{ Socioeconomic-Status $\alpha$} & Higho & 100 & 2.60 \\
\hline & Middlea & $179 a$ & 46.60 \\
\hline & Lowd: & $195 a$ & 50.80 \\
\hline
\end{tabular}

Source: Author's own

The respondents' demographic profile shows heterogeneous status. Among the total respondents $(\mathrm{N}=384), 51 \%$ male, $49 \%$ female and under the category $50.5 \%$ Scheduled Tribes and $49.5 \%$ were non- tribal. Location wise, respectively $47.9 \%$ were from rural and $52.1 \%$ from urban areas. Three groups were made based on the respondents' age: group-I (17 to 19 years,), group-II (19 plus years to 21 years but not exceeding 21 years) and group-III (21 to 23 years). The respondents' educational status was $49 \%$ studying in higher secondary and $51 \%$ were at their graduation level. Their socioeconomic statuses; only $2.6 \%$ of respondents were found belonging to high socioeconomic status and the highest $50.8 \%$ were in low SES.

Table: 2: Respondents' Aspirations Immediate to their Completion of College Education

\begin{tabular}{|c|c|c|}
\hline Aspirationa & Frequencyo & Percentageo \\
\hline To havea Jobo & 1240 & 32.30 \\
\hline To have an-Apprenticeshipo & 300 & 7.80 \\
\hline To start businesso & 100 & 2.60 \\
\hline To have skill trainingo & 230 & 6.00 \\
\hline To havehigher-Educationo & 1730 & 45.00 \\
\hline To-get -mamied andstay at homeo & 240 & 6.30 \\
\hline Totalo & 3840 & 100.00 \\
\hline
\end{tabular}

Source: Author's own

Immediate to completion of college education, the highest number of respondents $(45 \%)$ shared that they would opt for higher education and $33 \%$ of respondents expressed that they would go for jobs. Other areas related to immediate aspiration, the participants responded e.g. apprenticeship $(7.8 \%)$, starting a business $(2.6 \%)$, skill training $(6 \%)$ and getting married $(6.3 \%)$. Therefore, it is obvious fact that the majority of youth were concerned only in two things higher education and job. Importantly, in the area of job and apprenticeship, total percent was $40.1 \% \quad(32.3+7.8)$ indicating the very close difference with higher education aspirants. Moreover, $6.3 \%$ of respondents were found interested in getting married and staying at home. As of now in India higher education opportunity was not limited but talented youth and those of socio-economically privileged groups opted for it. Students belonging to lower SES groups had shown interest in early into the job markets. However gross enrolment in higher education increased very marginally $0.3 \%$ (Survey on Higher Education Report 2018). But youth aspiration for higher education was found very; Observer Research Foundation (ORF,2015) reported 96\% of the survey respondents opined for it; and $84 \%$ considered university degree as essential for their ideal placement.
Table: 3: Respondents' Aspirational role in their Future Career Life

\begin{tabular}{|c|c|c|c|c|}
\hline Ranko & $a$ & Role $^{\circ} \mathrm{d}$ & Frequency & Percentaged \\
\hline \multirow{3}{*}{ Higha } & 10 & $\begin{array}{l}\text { Doctor/Engineer } / \text { Architect//Actuary/Administrative- } \\
\text { Officer(govt.grade-A,B)\&-likely } \mathbf{A}\end{array}$ & $88 a$ & 22.90 \\
\hline & $2 \alpha$ & $\begin{array}{l}\text { Nurse/Teacher/-Accountant//Lawyer/Joumalist \& \& } \\
\text { likelyo }\end{array}$ & 165 & 43.00 \\
\hline & $3 a$ & Manager-and banker \& likely $\alpha$ & 250 & $6.5 \mathrm{x}$ \\
\hline \multirow{4}{*}{ Mediumo } & $4 a$ & Businessman $\alpha$ & 130 & 3.40 \\
\hline & $5 a$ & Political-Leader & 000 & $00 \%$ \\
\hline & 60 & Actor \& Artist (Musician \& \& entertainer \& likely)a & 100 & 2.60 \\
\hline & 70 & $\begin{array}{l}\text { Skilled Tradesman (Craftsman/Plumber/- Electrician. } \\
\text { \& likely) } \cdot \not\end{array}$ & 130 & $3.4 \alpha$ \\
\hline \multirow{3}{*}{ Low } & 80 & Clerk, office boy or-girl-\&-likely)a & 560 & $14.6 \mathrm{a}$ \\
\hline & 90 & Homemaker & 140 & 3.60 \\
\hline & $10 \mathrm{a}$ & Farmera & 000 & 000 \\
\hline & & Totalo & 3840 & 100.00 \\
\hline
\end{tabular}

Source: Author's own

The respondents were asked what professional or occupational and or job role they aspired to be in their future career. They shared their aspiration regarding future career roles that ranged from highly prestigious and well-paid one to lower one. Highest respondents $43.0 \%$ desired for professional role e.g. doctor/ engineer / architect/ actuary/administrative officer (govt. grade-A, B) and second-highest $22.9 \%$ respondents revealed that their aspirations for job roles were nurse/teacher/accountant/ lawyer/journalist and other likely roles. Interestingly, $14.6 \%$ of respondents' aspirational role was found to be clerical but not a single respondent was found preferring his or her future role as a political leader or a farmer. However, $3.6 \%$ of respondents articulated about their aspiration to be a homemaker. At this current era, every youth wanted to become someone big. Educated youth preferred to have a permanent job and govt. employment. As in public sector opportunities became meager, they considered professional courses for availing most opportunities in the job market. HT MARS POLL 2015 shared from Youth Aspiration Survey, only $9 \%$ aspired to pursue their passion of being professional in performing artist like actor, singer or musician etc. Observer Research Foundation (ORF,2015) report suggested $49 \%$ of youth preferred a job in the public sector.

Table: 4: Respondents' Aspiration that Considered as Achievement in Next 10 years of Life

\begin{tabular}{|c|c|c|}
\hline Possession and $\cdot$ Achievement ${ }^{\circ} \alpha$ & Frequencyo & Percentageo \\
\hline To have-dream job-(govt. jobs) any graded & 1310 & 34.10 \\
\hline To have-own *card & 690 & 18.00 \\
\hline To have-latest -electronic'gadgets $\alpha$ & 290 & 7.60 \\
\hline To have-stable-long relationship & $24 a$ & 6.30 \\
\hline To have family with children & $7 \alpha$ & 1.80 \\
\hline To -live-in-different part country & $10 \alpha$ & 2.60 \\
\hline To have-settle-in abroado & $13 \alpha$ & $3.4 \alpha$ \\
\hline To have beautiful wifea & $4 \alpha$ & 1.00 \\
\hline To have university-degreed & $35 a$ & 9.10 \\
\hline To have-own housed & 520 & $13.5 \alpha$ \\
\hline To become-famous & $10 x$ & 2.60 \\
\hline Totala & $384 \alpha$ & $100.0 x$ \\
\hline
\end{tabular}

Source: Author's own

Individual may have hundreds and thousands of things to aspire for in life. So the participants were enquired of their aspiration regarding any materialistic possession and anything else that they would reckon as their achievement in next the 10 years of their lives. The non-significant responses which were $<1 \%$, omitted and this table (4) only represents actual percent 1 and $>1 \%$. First of all, the majority $34.1 \%$ respondents' aspiration, they considered as the achievement was to have a govt. jobs and 
$18.0 \%$ respondents aspired to have own car and $13.5 \%$ desired to have their own house as a sign of achievement. It was found quite inconsistent to earlier finding (table 2 which demonstrated $45 \%$ respondents aspired to have higher education), whereas here (table4) only $9.1 \%$ respondents aspired to have a university degree in their possession as an achievement. It is obvious that there is a difference in aspiration level in immediate life situation and later life situation for any specific affair. Hence, this shows doxic nature of the participants' aspiration. The youth of this generation were more materialistic in their attitude towards life. Instant happiness became the motto of their life and they were found to not so futuristic (ORF,2015). It was because of consumerism and influxion of western culture.

To test hypotheses, first descriptive statistics were used and then the critical ratio of t-test was carried out in SPSS and with the help of an online tool, graphs are generated. The selected $\square \square$ is 0.05 level ( $\square \square \square$ ).

I. There is no significant difference between male and female in their level of aspirations

Table: 5: Student t-test, using Normal Distribution (two-tailed)

\begin{tabular}{|l|c|c|c|c|c|c|c|c|c|}
\hline \multirow{2}{*}{ Aspiration } & $\begin{array}{c}\text { Lerene's } \\
\text { Test for } \\
\text { Equality of } \\
\text { Variances }\end{array}$ & \multicolumn{9}{|c|}{ T-Test For Equality of Means } & \multicolumn{2}{c|}{$\begin{array}{c}95 \% \text { Confidence } \\
\text { Interval of the } \\
\text { Difference }\end{array}$} \\
\hline & F & Sig. & t & df & Sig & Mean Difference & Std. Error Difference & Lorrer & Upper \\
\hline Equal vaniances assumed & .022 & .882 & -2.111 & 382 & .035 & -1.639 & .776 & -3.165 & -.112 \\
\hline Equal vaniances not assumed & & & -2.112 & 381.947 & .035 & -1.639 & .776 & -3.164 & .1113 \\
\hline
\end{tabular}

Source: Author's own

The respondents' aspiration score was computed and it was found the mean score of the total respondents is 48.94 and male respondents' score is 48.13 whereas the female respondents' score was a little higher 49.77. The t-test result clearly indicated (table5) the difference between the two subgroups.

Graph: 1: Distribution of Male and Female respondents' Aspiration

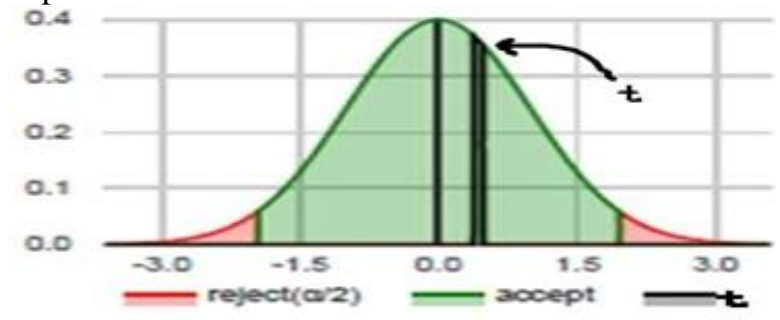

Source: Author's own

It is quite clear, since $\mathrm{p}$-value $<\alpha, \mathrm{H} 0$ was rejected. In other words, the difference between the average of the Male and Female was big enough to be statistically significant. P-value equals $0.0343742,(\mathrm{p}(\mathrm{x} \leq \mathrm{t})=0.0171871)$. This means that the chance of type1 error (rejecting a correct H0) was small: $0.03437(3.44 \%)$. The smaller the p-value the more it supports $\mathrm{H} 0$.The test statistic $\mathrm{t}=-2.115654$, was not in the 95\% critical value accepted range: [-1.9600:1.9600] x1-x2= -1.64 , was not in the $95 \%$ accepted range: [-1.5200: 1.5200]. Both male and female possessed almost equal level of aspiration, although the female's average aspiration was $49.77 \%$ which was comparatively higher. So to conclude, the youths especially female had high aspiration. There are studies which support the findings (Suzanne Naafs \& Tracey
Skelton (2018, Jennifer D. Shapka, José F. Domene \& Daniel P. Keating, 2006). Literacy and participation in higher education in many aspects changed social cognition and speeded up the message of gender neutrality. Media played an important role especially television (cable TV) mobile and internet, online social networking brought gender sensitization to the common mass in urban as well as rural areas. Hence, female comparative to male, showed higher level of aspiration. In HT MARS Poll it was found female $(49.7 \%)$ was ahead of male $(42.3 \%)$ in hope and ambition for future. Besides, different stimulus program by government for girl child might be considered as factor behind their rising aspiration. ORF study found $82 \%$ female youth preferring fulltime employment.

II. There is no significant difference between tribal and non tribal youth in their level of aspiration

Table: 6: Student t-test, using Normal Distribution (two-tailed)

\begin{tabular}{|c|c|c|c|c|c|c|c|c|c|}
\hline \multirow[t]{2}{*}{ Aspiration } & \multicolumn{2}{|c|}{$\begin{array}{c}\text { Lerene's } \\
\text { Test for } \\
\text { Equality of } \\
\text { Variances }\end{array}$} & \multicolumn{5}{|c|}{ t-test for Equality of Means } & \multicolumn{2}{|c|}{$\begin{array}{l}95 \% \text { Confidence } \\
\text { Interral of the } \\
\text { Difference }\end{array}$} \\
\hline & $\mathrm{F}$ & Sig, & $t$ & $\mathrm{df}$ & Sig. & Mean Difference & Std. Error Difference & Lotrer & Upper \\
\hline Equal variances assumed & 2.579 & .109 & .435 & 382 & .664 & .340 & .781 & -1.195 & 1.875 \\
\hline Equal variances not assumed & & & .435 & 374.262 & .664 & .340 & .782 & -1.197 & 1.877 \\
\hline
\end{tabular}

Source: Author's own

The respondents' aspiration score is computed and it is found mean score of the total respondents is 48.94 and Scheduled Tribe respondents' score is 49.10 whereas non-Scheduled Tribe respondents' score is little lower 48.76. And t-test result (table6) indicates not much difference between the two subgroups.

Graph: 2: Distribution of Scheduled Tribe and non-Scheduled Tribe respondents' Aspiration

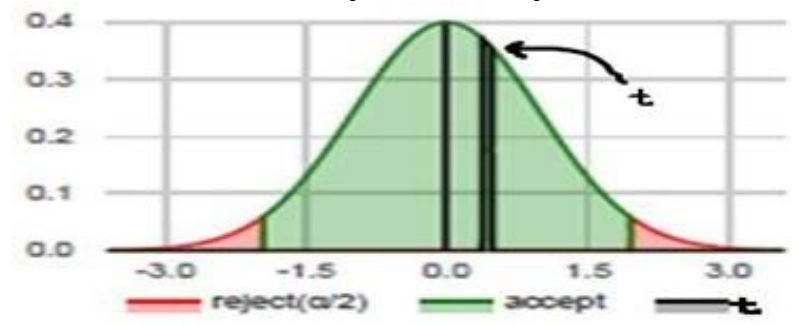

Source: Author's own

Unlike the previous the table value shows p-value was less; since $\mathrm{p}$-value $>\alpha, \mathrm{H} 0$ was accepted. In other words, the difference between the average of the ST and Non-Scheduled sample is not big enough to be statistically significant. $\mathrm{P}$-value equals $0.663436,(\mathrm{p}(\mathrm{x} \leq \mathrm{t})=0.668282)$. This means that if we would reject $\mathrm{H} 0$, the chance of type I error (rejecting a correct H0) would be too high: 0.6634 (66.34\%). The larger the p-value the more it supports $\mathrm{H} 0$. The test statistic $\mathrm{t}=0.435174$, is in the $95 \%$ critical value accepted range: $[-1.9600: 1.9600] \times 1-x 2=0.34$, is in the $95 \%$ accepted range: [-1.5300:1.5300]. The Scheduled Tribe and non-Scheduled Tribe respondents had shown difference in their level of aspiration. It resembles with studies carried out in developing countries where racial diversities exist (Caroline W Kabiru et al, 2013). Tribal and non-tribal youth was found differed in 
their aspiration level. Cities especially metropolis ones usually claimed for the face of development and aspiration of modernity but most rapid changes were also noticed in rural areas (Naaf's 2018). Residents of rural areas have been in transformation and that resulted in raise of aspiration in all walks of life and it is true to the tribal youth in India. Again stimulus package of youth developed programs exclusively meant for the tribal in the state was another positive cause; ORF studies found $60 \%$ of youth believed in favourable economic policies and government actions meeting their aspiration.

III. There is no significant difference in aspiration level of youth studying in rural and urban colleges.

Table: 7: Student t-test, using Normal Distribution (two-tailed)

\begin{tabular}{|l|c|c|c|c|c|c|c|c|c|}
\hline Aspiration & $\begin{array}{c}\text { Lerene's } \\
\text { Test for } \\
\text { Equality of } \\
\text { Variances }\end{array}$ & \multicolumn{9}{|c|}{ T-Test For Equality of Means } & \multicolumn{2}{c|}{$\begin{array}{c}95 \% \text { Confidence } \\
\text { Interval of the } \\
\text { Difference }\end{array}$} \\
\hline & F & Sig. & t & df & Sig. & Mean Difference & Std. Error Difference & Lorrer & Upper \\
\hline Equal variances assumed & .002 & .966 & 2.820 & 382 & .005 & 2.181 & .773 & .660 & 3.702 \\
\hline Equal variances not assumed & & & 2.824 & 381.080 & .005 & 2.181 & .772 & .663 & 3.700 \\
\hline
\end{tabular}

Source: Author's own

The respondents' aspiration score is computed and it is found the mean score of the total respondents is 48.94 and rural respondents' score is 47.89 whereas urban respondents' score is much higher 50.07. And t-test result (table7) indicates a difference between the two subgroups.

Graph: 3: Distribution of Rural and Urban College respondents' Aspiration

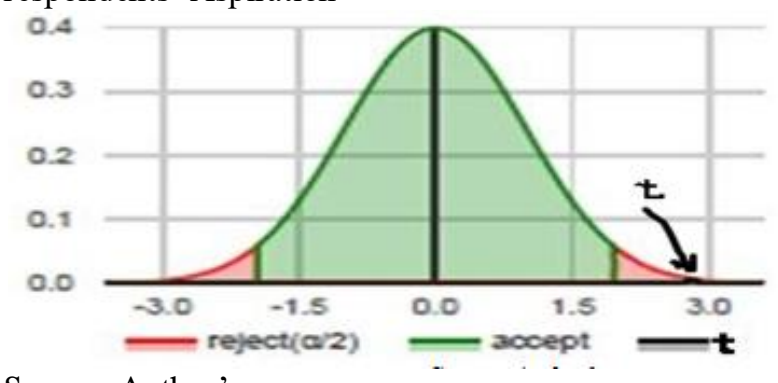

Source: Author's own

Since $\mathrm{p}$-value $<\alpha, \mathrm{H} 0$ is rejected. In other words, the difference between the average of the Rural and Urban sample is big enough to be statistically significant.2. P-value equals $0.00479568,(\mathrm{p}(\mathrm{x} \leq \mathrm{t})=0.997602)$. This means that the chance of type1 error (rejecting a correct $\mathrm{H} 0$ ) is small: $0.004796(0.48 \%)$. The smaller the p-value the more it supports $\mathrm{H} 0$. The test statistic $\mathrm{t}=2.820447$, is not in the $95 \%$ critical value accepted range: [-1.9600:1.9600] x1-x2=2.18, is not in the 95\% accepted range: [-1.5100:1.5100]. Findings of the study have significance; many studies (Cary M. Watson \& Teri Quatman 2002; Holly C. R 2005; Aron Linderman 2010; VM Messa 2015 and even studies in India e.g. Naik P. 2006, Samal R 2008) and others resembles with it. College education, exposures, lifestyle were important factors for urban youth for their higher level of aspiration. Urban lifestyle, competitive surroundings and access were main things; in urban areas parents were mostly educated and higher educated, so guidance to their children usually was more in comparison to corresponding rural areas. ORF (2015) research shared $51 \%$ of youth found 'asymmetry of information and lack of guidance were impending them from meeting their career aspiration'.

IV. There is no significant difference in aspiration level of youth belonging to different age groups.

Table: 8: ANOVA test, using Combined and within Groups

\begin{tabular}{|c|c|c|c|c|c|c|c|c|}
\hline Age groups & $N$ & Mean & & & Sum of Squares & $d f$ & Mean Square & $F$ \\
\hline $17.19 \mathrm{y} y \mathrm{~s}$ & 212 & 48.48 & \multirow{3}{*}{ Aspination" Age groups } & Between & 113814 & 2 & 56007 & 075 \\
\hline 19.21 ygs & 112 & 49.71 & & Grouss (Combined) & 15.017 & 2 & 50.201 & $.21 \%$ \\
\hline $21.23 \mathrm{ys}$ & 60 & 49.15 & & Within Groups & 2224.809 & 381 & 58.377 & \\
\hline Total & 384 & 48.94 & & & 22355.622 & 383 & & \\
\hline
\end{tabular}

Source: Author's own

The table8 displays results of descriptive statistics on the score of the respondents belonging to three different age groups and of One Way ANOVA. It shows the F value .975 derived from ANOVA which is significantly lower than its analogous F distribution table value (3.02) at significance 0.05 level. The sizes of three groups are not (n) equal, so a Post Hoc Test (Student-Newman-Keuls) is too carried out and its significance derived is .495 only at 0.05 levels. Therefore, the null hypothesis- aspiration levels of college-going youth belonging to different age groups are failed rejection. It can be said that different age groups, late adolescents, 19-21 years and early 20s groups possess a different level of aspiration. Perse, it can be explained that aspiration and age there is interrelation as age increases generally aspiration inclines but in this study, it's found with growing age, aspiration too increases, but it is very negligible. The finding supports other studies (Frostick, 2015 and Khattab, 2014).

$\mathrm{V}$ : There is no significant difference in aspiration level of youth belonging to different socioeconomic status groups.

Table: 9: ANOVA-test, using Combined and within Groups

\begin{tabular}{|c|c|c|c|c|c|c|c|c|}
\hline SES groups & ! & Mean & & & Sum of Squares & $d f$ & Dlean Square & $\mathrm{F}$ \\
\hline High & 10 & 46.50 & \multirow{2}{*}{ Aspiration "Socio Ecounomic Status } & $\begin{array}{l}\text { Betwean Groups } \\
\text { (Combined) }\end{array}$ & 907.42 & 2 & 453.721 & 8.060 \\
\hline \begin{tabular}{|l} 
Medirim \\
Low
\end{tabular} & \begin{tabular}{|l|}
179 \\
195 \\
\end{tabular} & \begin{tabular}{|l|}
50.58 \\
47.56
\end{tabular} & & Witim Groups & 21448.181 & 381 & 56.294 & \\
\hline Total & 384 & 48.94 & & & 22355.622 & 383 & & \\
\hline
\end{tabular}

Source: Author's own

The table9 displays descriptive statistics on the score of the respondents belonging to high, medium and low socioeconomic status groups and the result of One Way ANOVA. It shows, that the F value (8.060) derived through the analysis of variance is significantly higher than its analogous $\mathrm{F}$ distribution table value, which is 3.02 at significance 0.05 level. The sizes of three groups are not (n) equal, so a Post Hoc Test (Student-Newman-Keuls) is too carried out and its significance derived was 0.114 at 0.05 levels. Therefore, the null hypothesis: there is no significant difference in career aspiration level of secondary tribal school students belonging to high, medium and low socioeconomic status groups is rejected. It can be said that different groups- high, medium and low socioeconomic status groups possess a different level of career aspiration; tribal students belonging to three different socioeconomic groups differ to each other 
group in their level of career aspiration. Perse, it can be explained that career aspiration of youth was found to differ significantly with respect to their socioeconomic status. Such findings are found in studies carried by A.K Salgotra(2018), Gore, J., Holmes, K., Smith, M., et al. (2015) and others. Family's financial stability counted a lot in the mind of the young people (Yule 2013). Economic stability and affluence were important factors for higher SES group youth to have higher aspiration. It is family dynamics that indirectly influences all members of a family posited in a specific socioeconomic and cultural milieu. In case of tribal, family dynamics are different from the rest and sometimes this might also be found their families struggling hard for financial security; such context middle and low SES group youth differ in aspiration level in comparison to the higher SES group.

\section{IMPLICATIONS}

The findings hold certain implications in the context of youth and the state's development as well. National Youth Policy's (2014) first objective was to create 'productive workforce that can make a sustainable contribution to India's economic development'; one of the priority areas was 'education'. Matching with the finding it can be criticized that irrespective of caste or tribe or other societal and cultural differences the youth confirmed of their high aspiration exclusively for higher education, which can be considered as a positive indication for the productive workforce in future. In this study, the youth are found to be aspired to join in the workforce immediately after completion of their twelfth grade and Under Graduation (U.G) education. India Skills Report (2016) revealed only 37\% of the Employability Skill Test takers who were below the age of 30 years and there are studies that report in India approximately 70\%-75\% graduates were unemployable because of their lack of skills and technical knowledge. Now it is only $45.6 \%$ (UNDP, 2018) employable, so with the rising of the level of education, if they're not adequately placed, there are possibilities of creating educated unemployed youth. So the State needs to rethink over the education system and implement quality education fast to meet youth aspiration. Moreover, youth especially female's aspiration is found to be higher, their aspiration requires special attention if the state provides them good education and safe working environment, their participation in the workforces certainly increases and subsequently contributes more to the country's revenue. There is no difference between aspiration level of Scheduled and Non Scheduled youth. But more can be done with institutional level to accelerate the aspiration especially tribal and disadvantaged categories youth. As another priority was given in youth policy recommendation (NYP2014) for 'equitable opportunity for all disadvantaged \& marginalized youth', the state can play a proactive role in youth empowerment and development program prior to the upliftment and inclusive development of the tribals in the state. The Indian Youth Policy's another priority area was 'participation in politics and governance'; but in this study, youth found to have the least interest and aspiration for a career in politics. The state requires an arrangement of some mechanism to attract youth in politics.

\section{CONCLUSION}

Youth aspirations revealed by the students are highly correlated with those of the finding in the earlier studies. Youth in this region are aware of their personal growth, social progress and economic development; they believe that this can be possible only with education and good career. The caste-based social hierarchy; gender and socioeconomic status, hold differences that reflect in their level of aspiration. In the study, however, it is found, social hierarchy is not a so-called constraint for youth aspiration, as it finds rural youth comparatively to the urban, female comparatively to male, possesses greater level of aspiration. But this version of aspiration of youth can be doxic one (Doxic Aspiration). So importance should be given on social capital building; right kind infrastructure and youth-friendly service system may be modus operandi by which youth aspiration can be met. The study has shown overall aspiration of youth but in a glimpse, so the policymakers and developmental professionals can work upon with youth for social mobilization and inclusive development.

\section{REFERENCES}

1. Addressing the Situation and Aspirations of Youth, Issue brief-2: Prepared for the 2nd Meeting of the Global Commission on the Future of Work 15-17 February 2018 accessed from https://www.ilo.org/wcmsp5/groups/public/ on 5th June2019.

2. Bahadur Singh, Lai \& Kumar Singh, Arun \& Rani, Asha. (1996). Alienation: A Symptomatic Reaction of Educated Unemployed Youth in India. International Journal of Psychology. 31 10.1080/002075996401124.

3. Bandura, A. , Barbaranelli, C. , Caprara, G. V. and Pastorelli, C. (2001), Self-Efficacy Beliefs as Shapers of Children's Aspirations and Career Trajectories. Child Development, 72: 187-206. doi: $10.1111 / 1467-8624.00273$

4. Behera, P. and Samal, R. (2015) 'Category (Tribe and Non-Tribe) As a Factor in Educational Aspiration of Secondary School Student,s Journal of Research \& Method in Education 5 (4), 1-11

5. Bhanu, V.L (2006) Study on aspirations of rural youth and their attitude towards rural developmental activities in Dharwad district of Karnataka state; thesis accessed on 02/07/18 from http://krishikosh.egranth.ac.in/handle/1/80450

6. Caroline W Kabiru, Sanyu A Mojola, Donatien Beguy, Chinelo Okigbo (2014) Growing up at the 'margins': Concerns, aspirations, and expectations of young people living in Nairobi's slums, J Res Adolesc. 2013 Mar 1; 23(1): 81-94. doi: 10.1111/j.1532-7795.2012.00797.x PMCID: PMC4081599

7. Frostick, C., Phillips, G., Renton, A. and Moore, D. (2015) 'The educational and employment aspirations of adolescents from areas of high deprivation in London', Journal of Youth and Adolescence, 45(6), pp. 1126-40

8. Gharai, P. R., Panigrahi, J.K., Satpathy, I. and Das, B (2019) Value Creation through Agile Social Entrepreneurs toward Sustainable Development for Generation Next: A Unified Empirical Case Analysis, International Journal of Public Sector Performance Management (in Press)

9. Gore, J., Holmes, K., Smith, M. et al. (2015) 'Socioeconomic status and the Career Aspirations of Australian school students: Testing enduring Assumptions' Aust. Educ. Res. 42: 155.

10. Hindin, J and Hindin, M. J.(2009) Premarital Romantic Partnerships: Attitudes and Sexual Experiences of Youth in Delhi, India International Perspectives on Sexual and Reproductive Health Vol. 35, No. 2 pp. $97-104$

11. India Skills Report (2018) accessed from, ww.in.undp.org/content/india/en/home/library/poverty

12. Kao, G. and Tienda, M. (1998)Educational Aspirations of Minority Youth American Journal of Education 1998 106:3, Pages 349-384, www.journals.uchicago.edu, doi/abs/10.1086/444188

13. Khattab, N. (2014) How and when do educational aspirations, expectations and achievement align? Sociological Research Online, 19(4), 7 
14. Kunduri, E. (2016). Migration, informality and industrial labour markets: Examining representations of caste and gender in workers' narratives. Paper presented at conference on 'Examining Intersections: Caste/Gender Narratives in India’, 8-10 February, 2016, Institute of Development Studies, Kolkata, India.

15. Lukose, R. (2005). Consuming Globalization: Youth and Gender in Kerala, India. Journal of Social History 38(4), 915-935. Oxford University Press. Retrieved August 12, 2018, from Project MUSE database.

16. Mahendran A. (2015) Visible and Invisible Health Problems of Youth in India Pacific Business Review International Volume 8, Issue 4,

17. Malik et al. (2014), An Overview of Alienation among Unemployed Adults: A Literature Survey, Journal of Psychology and Psychotherapy ISSN: 2161-0487 JPPT, DOI: 10.4172/2161-0487.1000156

18. National Youth Aspirations Research Report, RA Ministry of Sport and Youth Affairs accessed from www.undp.org/content/dam/armenia/docs/ on 31st May2019

19. National Youth Policy (2014) document accessed from www.rgniyd.gov.in/sites/default/files/pdfs/ on 18th May 2019

20. Panigrahi, J.K., Tripathy, S. and Biswajit Das, B. (2017) Thematic analysis of Service Innovation taxonomy within supply network, creating value for the system, International Journal of Mechanical Engineering and Technology, 8(9), 57-69.

21. Paula McDonald and Barbara Pini and Janis Bailey and Robin Price\},(2011)Young people's aspirations for education, work, family and leisure, Work, Employment and Society, V-25, no-1 pp: 68-84

22. Quaglia, R. J., and Casey, C. D. (1996). Toward a theory of student aspirations. Journal of Research in Rural Education, 12, 127-132.

23. Rath, B.P., Panigrahi, J.K. and Das, B. (2018), Community Relations by Industries as a Part of Social Responsibility and Social Value Creation: An Empirical Case Analysis, International Journal of Mechanical Engineering and Technology, 9(3), 711-718

24. fSalgotra, A. K,(2018) "Educational Aspiration and Socio-Economic Status among Secondary School Students." IOSR Journal Of Humanities And Social Science (IOSR-JHSS). vol. 23 no. 03, 2018, pp. 25-29.

25. Satia J. (2018). Challenges for Adolescent Health Programms: What is needed?. Indian Journal of Community Medicine V-43, Suppl S1:15

26. Shapka J.D, Domene J.F and Keating D.P (2012) Trajectories of Educational Aspirations through High School and Beyond: A Gender Phenomenon" Canadian Journal of Education 35, 1 (2012): 239-258

27. Sivagurunathan, C., Umadevi, R., Rama, R., \& Gopalakrishnan, S (2015). Adolescent health: present status and its related programmes in India. Are we in the right direction?. Journal of clinical and diagnostic research : JCDR, 9(3), LE01-LE6. doi:10.7860/JCDR/2015/11199.5649

28. Staff, J. Harris,A. Sabates,R. \& Briddell, L. (2010); Uncertainty in Early Occupational Aspirations: Role Exploration or Aimlessness?, Social Forces, Volume 89, Issue 2, Pages 659-683,

29. Suzanne Naafs \& Tracey Skelton (2018) 'Youthful futures? Aspirations, education and employment in Asia', Children's Geographies, $16: 1, \quad 1-14, \quad$ DOI 10.1080/14733285.2018.1402164United Nations Development Program, Armenia

30. Vasabjit Banerjee, Srobana Bhattacharya \& Anand Jha (2017) Inequality and Elections: The Nationwide Origins and State-Level Dynamics of India's Maoist Insurgency, Asian Affairs: An American Review, 44:3, 72-97, DOI: 10.1080/00927678.2017.1357347 